\title{
A GUEST + A HOST = A GHOST. DRAMAS OF HOSPITALITY IN REBECCA WEST'S THE RETURN OF THE SOLDIER
}

\author{
Eleonora Natalia Ravizza* \\ University of Bergamo
}

\begin{abstract}
Rebecca West's novel The Return of the Soldier (1918) focuses on a common trope in Great War Literature: the traumas of war and the difficulties of returning veterans to fit back in with everyday life. The story of the shell-shocked soldier Chris Baldry, who suddenly finds himself in a world which has aged 15 years beyond his memory, may be read as the unfolding of a multi-layered drama of hospitality: Chris's memory erasure does not only turn him into a foreigner who does not recognize his wife or remember his dead son, but also forces his family members to question the role they have been playing in his life. An analysis of the novel's modernist techniques and stylistic features introduces a redefinition of the concept of hospitality in relation to trauma and disease. The Return of the Soldier may be read not only as a critique of war, but also as a multi-perspective narrative on the precariousness of host-guest relationships. The "question-of-the-foreigner" (Derrida, 2000) acquires new meanings when disease transforms a loved one into an "other" with whom communication seems to be interrupted. Hospitality may thus be regarded as an unstable concept, in which identity and alterity are constantly renegotiated.
\end{abstract}

Keywords: hospitality, alterity, literature ethics, war narrative, trauma.

\section{Introduction}

In his monumental project of tracing the conceptual genealogies and structures of signification of some of the key Indo-European behaviours and institutions, Émile Benveniste identifies two main roots to which the interconnected concepts of "hospitality" and "hostility" are etymologically

\footnotetext{
* eleonora.n.ravizza@gmail.com

This work is licensed under a Creative Commons Attribution-NonCommercial 4.0 International License.
}

Received: 04.02.2021

Revised: 20.04 .2021

Accepted: 19.05.2021

(C) The Author(s) 2021 
and semantically related. As the French linguist argues, both words derive from the Indo-European compound $<*$ hosti-pet (etymon of the Latin words hospes and hostis, signifying respectively "host"/"guest" and "foreigner/enemy"). While the stem pet (also present in words like despotes, or dominum) refers to "the person who personified the family group par excellence" (Benveniste, 2016, p. 61), and hints at the very concept of personal identity, the stem hosti conveys the idea of "equality by compensation: a hostis is one who repays my gift with a counter-gift".

Identity and reciprocity are indeed central semantic traits in the way we, even nowadays, understand the notion of "hospitality", and yet, when hospitality translates into concrete acts, they are also what is mostly put at stake. The complex etymological history of the word "hospitality" (and of its link to "hostility") mirrors the ambiguity and paradoxicality of a concept which entails simultaneously fundamental bonds and duties of solidarity, exchange and brotherhood, and the fear that those who are "foreign" or "other" may take over. The guest is the one who, as Jacques Derrida puts it, asks "the foreigner's question" (2000, p. 3): by insinuating him/herself inside the protected space of the host's home, s/he may reveal the very fragility, permeability and porosity of the host's self and undermine the very foundation of the latter's identity. In the Socratic dialogues, as the French philosopher reminds us, it is usually a foreigner who challenges the doxa, contests authority, and threatens the dogmatism of the law. Also, hospitality is a complex process of mediation which, more often than not, is inscribed in a dimension of power asymmetry, inequality, and difference, and in which tensions between host and guest, self and other, are never fully resolved. Even in the most cordial of invitations, "do as if you were at home", the "as if" signals precisely that there is an insurmountable discrepancy between having the formal rights of inhabiting a space and being (however warmly) accepted into it because of the gracious concession of someone else.

Host/ guest power dynamics have recently emerged as a particularly urgent cross-disciplinary preoccupation in light of the unprecedented crises that have marked the beginning of the new millennium. Current studies on hospitality especially draw on the reflections of Jacques Derrida (1999, 2000, 2000a, 2001), who engaged with the work of Émile Benveniste, Emmanuel Lévinas, and Immanuel Kant in order to address how the late 
twentieth-century social contexts of increased short- or long-term migration would bring along a renegotiation of national identities and boundaries. Derrida focused on the gradient of hostility in every act of hospitality, coining the word "hostipitality" from the above-mentioned Indo-European compound <*hosti-pet, to highlight how the concept of hospitality "is internally cannibalized by its opposite, "hostility"” (2000a, p. 3). "Hostipitality" appears as particularly relevant in a world shaped by the anxieties that 9/11 left in its wake (Still, 2010), as well as by intermittent refugee and migrant crises (Worth, 2006; Baker, 2009; Stronks, 2012; De Haene \& Rober, 2016, Franceschelli \& Galipò, 2020), climate disasters (Kelman, 2020), economic recessions (Czajka \& Isyar 2014), and global pandemics (Worth, 2006). Also, as the so-called age of digitization is bringing about a mobilization and fast-pacing of interpersonal and social relations, hospitality is also emerging as a creative process in which connections are produced, performed, sensed and consumed within a multiplicity of societies which, as Zygmunt Bauman phrased it (2000) are becoming ever more liquid (Whitlock, 2015; Germann Molz \& Gibson, 2007).

In the field of cultural and literary studies, the current interest in hospitality, hostility and the pleasures and hazards of intimacy is to be read through the lens of the so-called "ethical turn" - the recent resurgence of ethical approaches to literary texts, which are regarded as "a field of demonstration and testing ground for responsible and rewarding human behavior" (Grabes, 2008, p. 1). As a theme, hospitality traverses a multitude of literary texts from a variety of epochs and geographical contexts. In his comprehensive study on Hospitality and Treachery in Western Literature, James Heffernan (2014) analyzes examples from the Homeric poems, the Bible, Anglo-Saxon and Medieval poetry, Renaissance literature (Shakespeare), Romantic poetry (Wordsworth and Coleridge), eighteenth and nineteenth century French literature (Rousseau, Stendhal), late Victorian and modernist literature (James, Proust, Joyce, Woolf). The fact that welcoming the other exposes the self also to the risk of the other - an 'other' whose proximity may show how dangerously pervious the domestic space is, challenge the status quo, and reveal the vulnerability of our sense of self - reverberates in the literary text not simply as a theme, but mostly as textual dynamics. For example, Rachel Hollander's definition of "narrative 
hospitality" as an ethical paradigm "in which respecting the limits of knowledge and welcoming the stranger define fiction's relationship to both reader and the world" $(2013$, p.1), has prompted research on how fictions of hospitality, through creative manipulation of their narratological, semiotic and linguistic structures, contribute to the construction of new epistemological patterns to get to know and respect the other (Melville, 2007; Marais, 2009; Ridge, 2016; Ravizza, 2020). Narrative hospitality, as a matter of fact, differentiates itself from sympathy because, while the latter requires, to some extent, an assimilation of the other to the self, the former is based in the acknowledgement and acceptance of difference. Also, by focusing on the pragmatics and the reception of literary texts, Hollander uses Levinasian and Derridean reflections on alterity and hospitality as starting points to rethink literary ethics in terms of responsibility for the other, and to account for how the dynamics of textual production/ reception involve the reader as an active participant in the construction of new ethical and cognitive approaches to particularly urgent changes and demands (in the case of the late Victorian context she addresses, the woman question, workers' rights, colonial interactions).

It is precisely literature's capacity to creatively work through the semiotics of hospitality that has inspired the main research questions of this essay: what happens when the already precarious structure of hospitality is troubled by other elements, such as trauma and disease? How do literary texts allow us to appreciate the intricacies of host/guest relations when they are suddenly shaken by mental and/or physical diseases which contribute to undermining our deep sense of self, belonging and control? What happens when a loved one is suddenly turned into a foreigner?

First published in 1918, Rebecca West's debut novel The Return of the Soldier focuses precisely on how the return home of a shell-shocked soldier produces a multiplicity of what could be called "dramas of hospitality", in which the status of the soldier himself, his family and old acquaintances is constantly destabilized and renegotiated. West's novel deals with a common trope in Great War Literature: the traumas of war and the difficulties of returning veterans to fit back in with everyday life. As Captain Chris Baldry, an upper-class 35-year-old gentleman injured in France (most plausibly during the Somme offensive), is affected by a form of selective amnesia (he has forgotten the past fifteen years of his life, including his wife 
and his deceased one-year-old son), the legitimacy of his position as master of the house, his wedding, and the role that his family members play in his life are suddenly called into question. His memory erasure does not only turn him into a foreigner who does not recognize his wife or remember his dead son, but also shatters his family equilibrium. His wife suddenly becomes a stranger to him, while his long-lost love, a working-class woman well below his social standards who is initially introduced in the narrative as a stranger and a temporary visitor, becomes more important to him than anyone else. In the following sections, I argue that West's adoption of early modernist techniques, such as the limited focalization of the first-person intradiegetic narrator Jenny (Chris Baldry's cousin) and non-linear event reconstruction allow the conflicts and clashes within coexisting narratives of hospitality, in which characters may simultaneously be foreign and familiar, hosts and guests, to take shape. Jenny's own conflicts of loyalty (her sincere affection towards Chris, bordering romantic love, versus her awareness of social duties and responsibilities) form the basis of a complex representation of mental disorder which takes into consideration not only the sufferer, but also the interpersonal relations of familiarity and estrangement that disease constantly deconstructs and reconstructs.

\section{A guest plus a host equals a ghost. Chris Baldry and interpellation}

Whenever we think of host-guest relationship, we imagine two distinctive, well defined positions which, certainly, in due course, may be exchanged, but which do not usually overlap, or form a continuum. When hospitality is agreed, as a matter of fact, the two contracting parties' identities need to be well established. A guest cannot simultaneously be his/her host's host unless, of course, s/he becomes a usurper, and breaks the very pact of hospitality - and we expect a host to become his/her guest's guest only at some future time. In The Return of the Soldier this assumption is challenged when the memory loss which affects Chris Baldry undermines his status as master of the house, and produces two conflicting narratives of identity. In one, Chris is the happy landlord of a wealthy English household, obediently serving his Country in France during the Great War but firmly tied to his land by duty (as his wife Kitty, engaged in the charitable tasks of making clothes for the poor reminds him, "'We - We've a lot of responsibilities, 
you and I. With all the land you've bought there's ever so many people to look after....", West, 2018, p.42). In the other, Chris, who believes he is still the carefree twenty-year-old son of a well-to-do landowner, forgets about his current family ties, and his only priority is the unconditional love he still bears for his first love, Margaret Grey (née Allington), a worn out, lower class woman now married to another man. The first narrative also sustains the fictions of identity of those who live with him: of Chris' wife in the first place, whose position in life is determined by her being married to him and presiding over their household, but also of his (secretly enamoured) cousin Jenny, who lives with the couple and relies on the certainty that Chris belongs in Baldry Court (she expresses her confidence at the beginning of the novel: "This house, this life with us, was the core of his heart", West, 2018, 9). The second narrative, instead, by allowing Chris' subconscious to emerge (i.e. his obsessions, his repressed love and sexual desire for Margaret, the fact that he does not love, or even like, his wife) exposes the frailty of the first and endangers the position of all the other characters. If Captain Baldry has not become accustomed with the idea of being the head of a new family yet, and has become an unrecognizable, romantic stranger who disowns his wife, does not remember his son and cannot be burdened with responsibilities, does he re-enter his house as a host, or rather as a guest? Is the sick, traumatized Chris Baldry the same person as the one who left to fight in the war? And what about Kitty, who responds to her husband's sickness with profound hostility, and who is dispossessed of her role as Chris' companion by a stranger, someone who enters her house as an unwelcome guest?

In the title of this essay, I borrowed a pun written by Marcel Duchamp on the wrappers of some candies distributed during Bill Copley's 1953 Parisian show (Gould, 2000). "A guest + a host $=$ ghost" humorously suggests that the blending of two opposite words ("guest" and "host") leads to their annihilation (a ghost). In The Return of the Soldier, as Chris" position within the hospitality spectrum is oscillating between two opposite poles, Chris emerges as an ever more phantasmatic figure. Haunted by two traumatic experiences, his child's death and the horrors of war, Chris escapes his reality and finds shelter in the memory of his first love, something which is now foreclosed to him. The specter of his repressed, romantic self, which has suddenly resurfaced after a wound in the head, 
precipitates his family into the dimension of the Freudian unheimlich: the familiar that uncannily becomes something else. We could also say that his persona is split into two. On the one hand, we have Chris as the signifier of masculinity, order and stability, and on the other, we have the sick, "phantasmatic" Chris, who refuses to be identified with those concepts, and exposes the insurmountable discrepancy between the signifier and the (latent) signified.

That Chris may be considered as a ghost is also reflected in the fact that he is introduced in the story as an absence, and that his narrative circle is completed, as we shall see in the next section, when he leaves his home again, returning to war and to a most probable death on the battlefield. The first chapter shows that his family continue to project their expectations onto the absent Chris, and that they perform their roles as if he were still there, a figure of authority and a simulacrum of masculinity presiding over the ordinary course of things. The idea of performance recurs in the novel with particular reference to the façade of beauty, amiability and grace that Kitty puts on as she tends to her wifely duties and behaves like the perfect landlady. Her almost military efficiency and despotism towards the other inhabitants of the house (Jenny included), which, as Melissa Edmundson notes (2008, pp. 492-493), are even more accentuated in the early editions of the novel, certainly allow the reader to see her as "the home front equivalent to British militarism during the First World War and the unforgiving, masculinist mindset that led England into war" (Edmundson, 2008, p. 493). The very incipit of the novel stresses her need to show selfcontrol and propriety: “'Ah, don't begin to fuss!' wailed Kitty. 'If a woman began to worry in these days because her husband hadn't written to her for a fortnight-!'” (West, 2018, p. 3). Although the reporting verb in this short passage (i.e., "wailed") betrays an emotionally intense moment - after all, Jenny, the addressee of Kitty's outburst, has just found her pining over the bed of hers and Chris' dead son - Kitty clings to the idea that life should carry on according to pre-established social patterns of behaviour, to which she attends as her status prescribes.

The idea of performance traverses the first encounter between Kitty, acting as the perfect hostess, and Margaret, in the role of the unexpected and not particularly distinguished guest. The contrast between the two women is striking: the more elegant, assuming, and beautiful the one, the more 
frumpy, unsophisticated, and unattractive the other. Hospitality is one of those duties which Kitty carries out with particular zeal as she deputizes for her absent husband, but playing the perfect hostess is not synonymous with being a warm-hearted one. Wishing to remark Margaret's insignificance, she announces to Jenny that she is not going to put too much effort in receiving such a humble guest ("As the girl went, she took up the amber hairpins from her lap and began swathing her hair about her head. 'Last year's fashion' she commented, 'but I fancy it will do for a person with that sort of address.", West, 2018, p. 12). If Kitty does not expect reciprocity and friendship from Margaret, nevertheless she expects that her hospitality is repaid with her being recognised as a good wife and, although her expression is marked with an ironic undertone, as a good Christian (Kitty says: "I I am seeing her because she may need something, and I specially want to be kind to people while Chris is away. One wants to deserve well of Heaven"', West, 2018, p. 12). Yet, Margaret is not there to beg for money or help; on the contrary, she is offering valuable information regarding Chris, slightly tilting the power balance to her side. So, as Margaret does not play by the rule set by her hostess, and the performance starts to become more dramatic than expected, she is openly accused of being a swindler trying to exploit Chris' family's vulnerability to extort some money.

Kitty and Margaret's verbal exchange may be described as a game of interpellation (Althusser, 1971) in which Chris is produced as a different type of subject according to the linguistic structure though which he is evoked during the conversation. What is put at stake, in other words, is both Chris' identity and the three women's relationship to him (Jenny also participates in the scene as Kitty's chaperone). At first, when Margaret claims that she knows something about the soldier that his wife does not, she timidly and apologetically refers to him as "Mr Baldry" ("Forgive me, I don't know his rank", West, 2018, p. 14). Kitty intervenes immediately and supplies the correct title ("Captain Baldry", West, 2018, p. 14), one which should definitely establish the proper, formal distance between her husband and the shabby lady sitting in front of her. As Margaret informs Kitty and Jenny that Chris is wounded, and the two women refuse to believe her or take action, she shouts "But Chris is ill!" (West, 2018, p. 18). The use of the soldier's first name, to which only intimates are entitled, is perceived as a direct accusation to his family members, as Jenny words' show: 
It took a second for the compact insolence of the moment to penetrate: the amazing impertinence of the use of his name, the accusation of callousness she brought against us, whose passion for Chris was our point of honour, because we would not shriek at her falseness, the impudently bright indignant gaze she flung at us, the lift of her voice that pretended she could not understand our coolness and irrelevance. (West, 2018, p. 18)

Margaret's intimacy with the person she dares to call "Chris" calls into being a new scenario, one which sabotages Jenny and Kitty's definition of their own selves ("us, whose passion for Chris was our point of honour"), and directly accuses them of being callous. What Jenny resents is the fact that Margaret is abusing her privilege as a guest (an attitude which, in the passage, is referred to as "impertinence"). Nevertheless, her story is supported with the tangible proof of a telegram written to Margaret by Chris himself - a manifestation of the absentee (i.e. the ghost) which shows that he cares more for a stranger than for his family. The first chapter finishes with Kitty's observation that "If he could send that telegram he isn't ours any longer" (West, 2018, p. 23), signaling, on the one hand, the refusal of the story line called into existence by Margaret's "But Chris is ill" (West, 2018, p. 14) and, on the other, a new interrogative regarding Chris: if he is not ours anymore, does he belong to this unkempt lady who has crossed the threshold of our cherished home? Where does this leave us?

Jenny's limited point of view is nevertheless a mobile one. While the first chapter shows her adherence to Kitty's perspective and her firm belief in the narrative according to which "there never was so visibly contented a man" as Chris (West, 2018, 8), throughout the next five chapters she starts to become more open and hospitable towards Chris' sickness and, by reflection, towards Margaret. Despite her repulsion towards Chris' first love, who "was not so much a person as an implication of poverty" (West, 2018, p. 104), Jenny starts to appreciate a foreign point of view - that of the sick Chris, who loves Margaret despite her status or appearance (he says to Jenny: "If you had seen the way she rested her cheek against the glass and looked into the little room, you'd understand that I can't say, 'Yes, Kitty's my wife, and Margaret somehow just nothing at all'”, West, 2018, p. 62). It 
is by gradually starting to see things through Chris' eyes that Jenny progressively becomes able to acknowledge Margaret as a generous woman, willing to overcome her own ghosts (such as the tragedy of her son's death), in order to help Chris to come back to his "sane" self. As this perspective, at the beginning of the novel, is presented as completely extraneous to Jenny's understanding of herself, Chris, and Baldry house, Chris's cousin needs to elaborate some new strategies to understand the situation:

I could not think clearly about it. I suppose that the subject of our tragedy, written in spiritual terms, was that in Kitty he had turned from the type of woman that makes the body conqueror of the soul and in me from the type that mediates between the soul and the body and makes them run even and unhasty like a well-matched pair of carriage horses, and had given himself to a woman whose bleak habit it was to champion the soul against the body. But I saw it just as a fantastic act of cruelty that I could only think of as a conjunction of calamitous images. (West, 2018, p. 100)

The passage shows that Jenny is struggling to find a way to include 'the foreign' into her own way of seeing - she is, differently put, elaborating linguistic strategies to allow a new form of narrative hospitality to emerge, in which Chris' sickness and obsession with a woman like Margaret may begin to be understood as acceptable. The conflict of sense and meaning that are traversing Jenny's mind emerge through the fact that her description of the family "tragedy" seems to undermine itself. The dichotomy she drafts Kitty as the woman who prioritizes appearances over substance, Margaret as the one who values empathy and emotions over formality ("to lovers innumerable things do not matter”, West, 2018, p. 89), and Jenny as a sort of go-between - shows that, in a way, Jenny is willing to accept Margaret, but not fully. The commonly accepted superiority of the soul over the body is transformed into something uncanny - the "conjunction of calamitous images" that Jenny evokes suggests she is afraid of Margaret's alterity, an alterity which has also forced her to see Chris' alienation for the first time. 


\section{Healing Chris: The end of narrative hospitality?}

In the previous section I have shown that Chris' post-traumatic stress disorder makes him oscillate between being a host (the owner of Baldry Court and Kitty's husband) and a guest (a sick 'other', the haunting reemergence of a repressed self). What seems to trouble Kitty the most is the fact that within Chris' persona, the signifier of what he stood for (an adult, a husband, a landowner) does not match with the new signified. Chris, as Jenny puts it in the extract quoted above, turns from his corporeal and material dimension, to embrace a spiritual one in which he can appreciate "Margaret as she existed in eternity" rather than "Margaret as she existed in time" (West, 2018, p. 73). Kitty's confidence in the correspondence between signifier and signified allows her to cope with Chris' physical absence. Paradoxically, when Chris is at home, his bodily presence does not correspond to a spiritual one: the ghost of his young romantic self haunts the identity and serenity of his family. So, in Kitty's mindset, it is preferrable that Chris is away, at war, but reconciled with his adult self, rather than a stranger at home. In her perspective, the novel has a happy ending, in spite of the fact that Chris will have to leave soon. The game of interpellation which began in the first chapter finally draws to an end when Chris begins to accept the words of his psychiatrist, Dr. Anderson, "[y]ou [...] are the patient" (West, 2018, p. 114) and undergoes a healing process in which Margaret plays a key role. The novel ends with Kitty and Jenny observing Chris suddenly regain his military gait and attitude, and Kitty commenting "Every inch a soldier" (West, 2018, p. 138). Kitty is in fact the one who pronounces (twice) the novel's explicit: "He is cured" (West, 2018, p. 138).

The ending shows the expulsion of the sick, alien Chris (certainly soon to be followed by the unwelcome Margaret), and the return of the sane Chris (who will soon set off to the front). Yet, the circle is not fully closed. Although the novel's ending has been described as an example of "extreme sanism" (Linnett, 2013, n.p.) because it seems to imply that a return to a socalled normality is a necessity and not a choice, the idea of sanity is deconstructed through the hospitable approach which Jenny develops throughout her narration. Being hospitable, as Rachel Hollander shows in her analysis of late Victorian novel (2013), does not simply mean to identify and sympathize with the other. Narrative hospitality, as a matter of fact, 
should be understood as an effort to portray and enact ways to harbour 'otherness' in terms of both relationality and conflict.

The fact that 'self' and 'other' are never fully conflated in Jenny's narrative is particularly evident when she describes Chris' cure. Her narration, as a matter of fact, continually oscillates between an attitude of refusal - equally towards Margaret and Chris' sick self - and one of acceptance. For example, when Margaret is about to meet Dr. Anderson, she is irritated by the woman's "awful clothes", and she addresses the latter in a way that makes her conscious of her inferiority: "I turned to Margert an expression which conveyed that this was an act of hospitality, the refusal of which we would find wounding, and to that she yielded and I knew she would" (West, 2018, p. 117; interestingly, in the passage, the word "hospitality" is used to signal distance and asymmetry of power). Yet, Jenny's irritation at seeing Margaret inside the sancta sanctorum of Chris's son room is counterbalanced by her effort to understand her guest, and even by timid attempts at liking her (for example when she says that "Margaret reassumed her majesty", West, 2018, p.121, or when she suddenly realizes that she must have been a mother).

The last part of the novel depicts a dramatic dialectics between two different perspectives on what sanity actually means. Margaret astonishes her hostesses by objecting to the doctor's approach by saying: "'You can't cure him. [...] Make him happy, I mean. All you can do is to make him ordinary" (West, 2018, p. 125). The cure, as a matter of fact, has to be terrible: with the help of Margaret, who has also experienced loss and tragedy in her life, Chris will need to confront the traumas of his past. Jenny is torn between the realization that "that is the kind of things one has to do in his life" (West, 2018, p. 127), and that what is going to happen is not going to be completely fair to Chris: "It became plain that if madness means a liability to wild error about the world, Chris was not mad. It was our peculiar shame that he had rejected us when he had attained to something saner than sanity. His very loss of memory was a triumph over the limitations of language which prevent the mass of men from making explicit statements about their spiritual relationships" (West, 2018, p. 99). Alterity, differently put, has enacted a deconstructive game, in which Jenny begins to question all certitudes about herself and her vision of the world. Kitty's final, victorious proclaim "He is cured" does not signal that signifier and 
signified are finally united, but rather that the true meaning of sanity, as well as of Chris, is forever foreclosed.

\section{Conclusion}

In this essay I have dealt with how the Derridean concept of hospitality may productively allow us to understand the way trauma and disease are not just an individual tragedy but are inscribed within a network of relationships. Being sick calls into questions not just one's identity, but also the nets of relationships that bind the individual to his/her family, close friends, and even society. Jenny's imperfect account shows how literature may be regarded as a testing ground to find complex ways to simultaneously express a desire to welcome the 'other' (her dearest Chris, but also his mental disease and, to a certain extent, Margaret) and the discomfort of the encounter with a resistant 'otherness,' one which demands an ethical response to an unpredictable, and possibly disruptive request for acknowledgement. As Jacques Derrida reminds us, hospitality (or rather "hostitpitality") is a complex process of mediation in which tensions are never fully resolved, but rather become part of a dynamic and dialogic relationship in which 'self' and 'other' never conflate.

Chris Baldry's story acquires significance not only in relation to his private, familial context, but more generally, within a context of a critique to military values, patriarchalism, and class-bound behavioural norms. As Jenny progressively understands that another narrative (beside the one to which she and Kitty clang at the beginning of the novel) is possible she also begins to deconstruct the very values which supported her previous worldview. Literature emerges thus as a precious tool to elaborate the complexity of life and change the semiotics according to which we make sense of the world.

\section{References}

Althusser, L. (1971). Ideology and ideological state apparatuses: Notes towards an investigation (B. Brewster, Trans.). In L. Althusser. Lenin and Philosophy and Other Essays (pp. 127-186). New York, NY: Monthly Review Press. (Original Work published in 1970). 
Baker, G. (2009). Cosmopolitanism as hospitality: Revisiting identity and difference in cosmopolitanism. Alternatives: Global, Local, Political, 34(2), 107-128. https://doi.org/10.1177/030437540903400201.

Bauman, Z. (2000). Liquid modernity. Cambridge and Malden, MA: Polity Press.

Benveniste, E. (2016). Dictionary of Indo-European concepts and society (E. Palmer, Trans.). Chicago, IL: Hau Books. (Original work published in 1969).

Czajka, A., \& Isyar, B. Europe after Derrida: Crisis and potentiality. Edinburgh University Press.

De Haene, L., \& Rober P. (2016). Looking for a home: An exploration of Jacques Derrida's notion of hospitality in family therapy practice with refugees. Everything is Connected Press, 2016.

Derrida, J. (1999). Adieu to Emmanuel Levinas (P. A. Brault, Trans.). Redwood, CA: Stanford UP.

Derrida, J. (2000). Of hospitality. Anne Dufourmantelle invites Jacques Derrida to respond (R. Bowlby, Trans.). Stanford University Press.

Derrida, J. (2000a). Hostipitality (B. Stocker \& F. Morlock, Trans.). Angelaki. Journal of the Theoretical Humanities, 5(3), 3-18.

Derrida, J. (2001). On cosmopolitanism and forgiveness (M. Dooley \& M. Hughes, Trans.). London and New York, NY: Routledge.

Edmundson, M. (2008). Complicating Kitty: A textual variant in Rebecca West's 'The Return of the Soldier'. Notes and Queries, 55(4), 492493.

Franceschelli, M., \& Galipò, A. (2020). Exploring practices of hospitality and hostility towards migrants through the making of a documentary film: Insights from research in Lampedusa. In E. Fiddian-Qasmiyeh (Ed.), Refuge in a Moving World: Tracing refugee and migrant journeys across disciplines (pp. 94-110). London: UCL Press.

Germann Molz, J., \& Gibson S. (2007). Mobilizing hospitality: The ethics of social relations in a mobile world. Aldershot: Ashgate.

Gould, S. J. (2000). The substantial ghost: Towards a general exegesis of Duchamp's artful wordplays. Tout-Fait. The Marcel Duchamp Study Online Journal, 1(2). https://www.toutfait.com/issues/issue_2/Articles/gould.html. 
Grabes, H. (2008). Introduction. In A. Erll, H. Grabes, \& A. Nünning, A. Ethics in culture the dissemination of values through literature and other media (pp. 1-15). Berlin and New York, NY: Walter de Gruyter.

Heffernan. J. A. W. (2014). Hospitality and treachery in western literature. New Haven and London: Yale University Press.

Hollander, R. (2013). Narrative hospitality in late Victorian fiction. Novel ethics. London and New York, NY: Routledge.

Kelman, I. (2020). Does climate change cause migration? In E. FiddianQasmiyeh (ed.), Refuge in a moving world: Tracing refugee and migrant journeys across disciplines (pp. 123-136). London: UCL Press.

Linett, M. (2013). Involuntary cure: Rebecca West's 'The Return of the Soldier'. Disability Studies Quarterly, 33(1). http://dx.doi.org/10.18061/dsq.v33i1.3468

Marais, M. (2009). Secretary of the invisible. The idea of hospitality in the fiction of J.M. Coetzee. Amsterdam and New York, NY: Rodopi.

Melville, Peter. (2007). Romantic hospitality and the resistance to accommodation. Waterloo, Canada: Wilfrid Laurier University Press.

McNulty, T. (2007). The Hostess: hospitality, femininity, and the expropriation of identity. University of Minnesota Press.

Ravizza, E. N. (2020). Poetic hospitality. The dramatic monologue as a postmodern, neo-Victorian genre. European Journal of English Studies, 24(3), 268-282.

Ridge, E. (2016). Threshold anxieties: (In)hospitality, the English novel and the second world war. Literature Compass, 13(7), 481-490.

Still, J. (2010). Derrida and hospitality. Edinburgh University Press.

Stronks, M. (2012). The Question of Salah Sheekh: Derrida's hospitality and migration law. International Journal of Law in Context, 8(1), 7395. https://doi.org/10.1017/S1744552311000449

West, R. (2018). The Return of the Soldier. London: Virago Press. (Original work published in 1918).

Whitlock. G. (2015). The Hospitality of cyberspace: Mobilizing asylum seeker testimony online. Biography (Honolulu), 38(2), 245-266.

Worth, H. (2006). Unconditional hospitality: HIV, ethics and the refugee problem. Bioethics 20(5), 223-232. 


\section{A GUEST + A HOST = A GHOST.

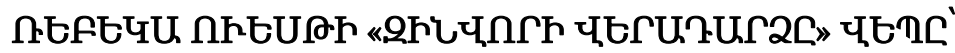

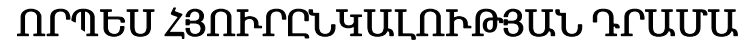

\section{Eltninnu Uuinuipu nul|hgu}

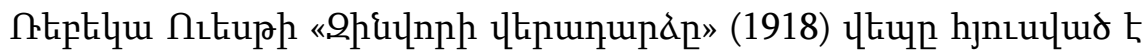

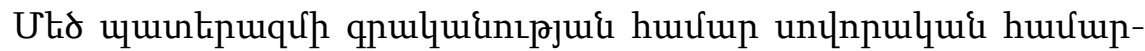

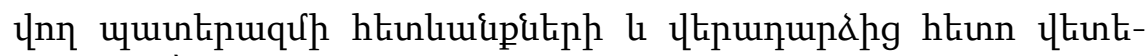

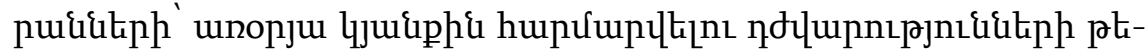

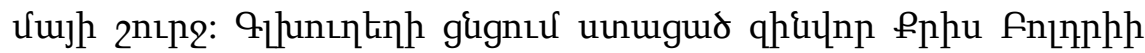

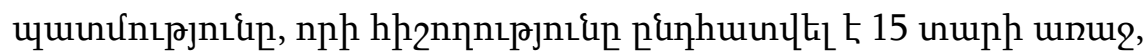

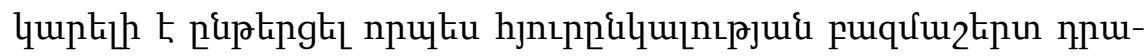

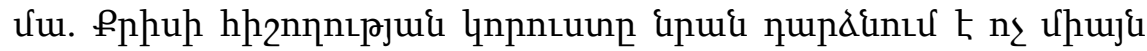

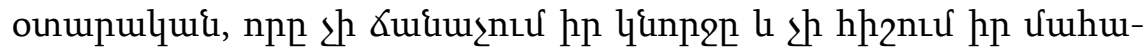

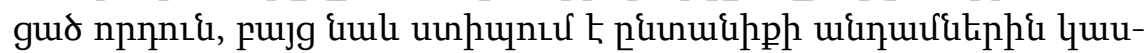

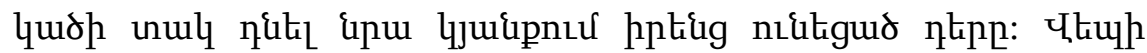

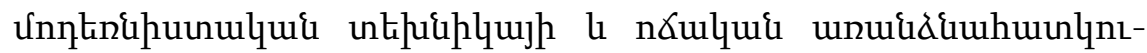

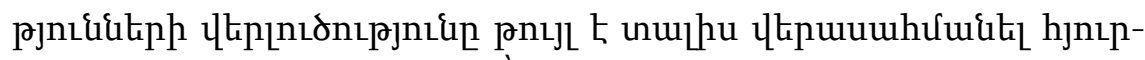

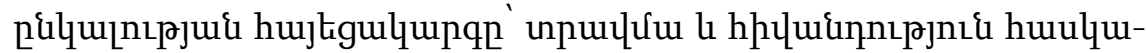

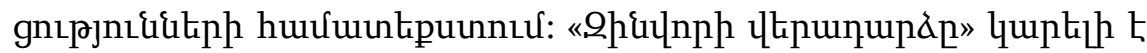

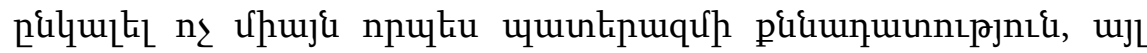

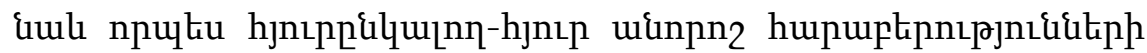

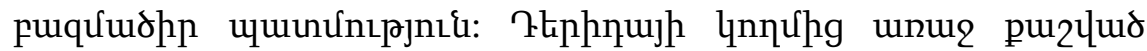

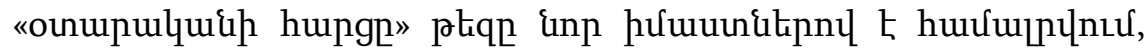

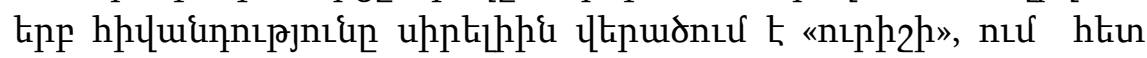

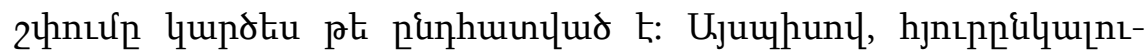

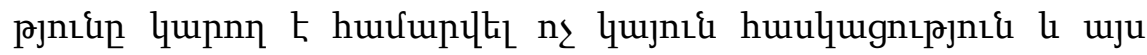

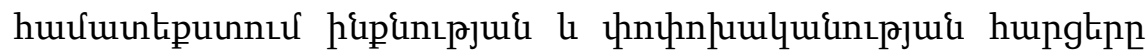

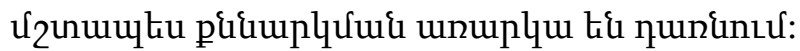

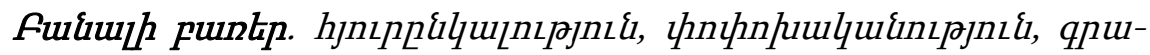

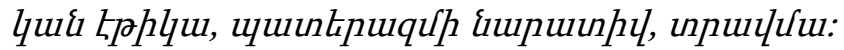

